\title{
Sistem Kendali Governor Pembangkit Listrik Tenaga Diesel Berbasis Mikrokontroller
}

\author{
Elfizon \\ Dosen Jurusan Teknik Elektro, Fakultas Teknik Universitas Negeri Padang \\ elfizondft.unp.ac.id, elfizon24@gmail.com
}

\begin{abstract}
Abstrak - Penelitian ini bertujuan merancang sistem kendali untuk mengoptimalkan fungsi alat kontrol suplai bahan bakar pada sistem PLTD dalam rangka menghasilkan kwantitas pembakaran yang tetap untuk putaran yang konstan. Alat yang dimaksud adalah sistem kendali Governor UG40 dengan berbasiskan Mikrokontroller AT89S52. Sistim kerja alat yang dirancang ini adalah dengan mengambil input dari generator berupa Frekuensi, Frekuensi ini dirobah dalam bentuk tegangan, karena tegangan ini masih kecil dan belum sesuai dengan kondisi yang dibutuhkan maka dinaikkan melalui Op-amp, kemudian tegangan tadi dirobah dalam bentuk digital melalui rangkaian ADC dan di inputkan pada mikrokontroller AT89S52. Hasil perancangan alat ini ditujukan untuk menagatur bukaan katub governor. Apabila frekuensi kurang dari $48 \mathrm{~Hz}$ maka peralatan ini akan mengatur putaran motor ke kanan, sebaliknya apabila frekuensi lebih dari $50 \mathrm{~Hz}$ maka peralatan ini akan mengatur putaran motor ke kiri. Berdasarkan hasil perancangan alat dapat disimpulkan bahwa motor akan bkerja diluar set point sehingga efek yang dihasilkan mesin diesel akan disesuaikan dengan frekuensi melalui sistem makanis governor.
\end{abstract}

Kata kunci - Governor, FTV, Op-Amp, ADC, dan Mikrokontroller

\section{PENDAHULUAN}

Kebutuhan terhadap tenaga listrik selalu meningkat dari waktu ke waktu dan merupakan suatu tuntutan yang senantiasa harus dipenuhi dalam menunjang produktivitas. Seiring dengan meningkatnya kebutuhan akan daya listrik tersebut maka energi yang diperlukan juga akan bertambah. Dalam penambahan energi listrik haruslah memperhatikan berbagai hal terutama keandalan dari energi lstrik yang di salurkan. Contohnya dalam dunia industri, energi listrik yang handal sangat menentukan dalam mencapai target produksi perusahaan.

Terkait terhadap keandalan tenaga listrik ini maka bagi pihak penyedia tenaga harus selalu memperhatikan berbagai faktor yang menyangkut kualitas energi listrik yang disalurkan. Satu diantaranya adalah pada sistem pembangkitan, dimana faktor nilai dan besaran sangat berpengaruh tehadap kualitas energi listrik yang disalurkan. Nilai dan besaran sistem tenaga listrik tersebut harus memenuhi standar yang diperlukan untuk pembangkitan energi listrik sesuai dengan nilai nominal yang ditetapkan.
Berdasarkan prinsip dasar pembangkitan maka faktor RPM (Rotation Per Minutes) merupakan salah satu faktor yang sangat menentukan terhadap tegangan yang dihasilkan. Untuk itu semua unsur yang menyangkut kestabilan putaran ini harus diperhatikan.

Seperti diketahui bahwa pada mesin diesel, yaitu sebuah mesin pemicu kompresi, dimana bahan bakar dinyalakan oleh suhu tinggi gas yang dikompresi, dan bukan oleh alat berenergi lain (seperti busi). Ketika gas dikompresi, suhunya meningkat, Udara disedot kedalam silinder mesin diesel dan dikompresi oleh piston yang merapat, jauh lebih tinggi dari rasio kompresi dari mesin menggunakan busi. Pada saat piston memukul bagian paling atas, bahan bakar diesel dipompa keruang pembakaran dalam takanan tinggi, dicampur melalui udara panas yang bertekanan tinggi. Hasil pembakaran ini menyala dan membakar dengan cepat.

Ledakan tertutup ini menyebabkan gas dalam ruang pembakaran diatas menggembung, mendorong piston ke bawah dengan tekanan yang kuat dan menghasilkan tenaga dengan arah vertikal. Tuas penghubung menyalurkan gerakan ini ke crankshaft (Poros Engkol) yang dipaksa untuk berputar, menghantar tenaga berputar di ujung pengeluaran crankshaft.

Jadi sistem mekanik pada PLTD diperlukan untuk menyediakan dan menjaga suatu putaran dengan suatu kecepatan (RPM) tertentu sebagai salah satu syarat atau variabel yang harus dipenuhi untuk menghasilkan tegangan (E) dengan besaran yang ditentukan. Pada PLTD kehandalan dan keseimbangan sistem mekanik sangat berkaitan dan berpengaruh terhadap kehandalan sistem tenaga listrik yang dihasilkan.

RPM yang dihasilkan oleh mesin sebagai suatu output dari proses pembakaran besarnya tentu ditentukan oleh supply bahan bakar untuk pembakaran tersebut. Jika supply bahan bakar ditambah atau diperbesar maka pembakaran di dalam silinder mesin akan meningkat, sehingga RPM akan bertambah cepat dan sebaliknya jika supply bahan bakar dikurangi maka putaran mesin juga akan berkurang. Untuk mendapatkan nilai tegangan yang sesuai dengan nilai yang ditetapkan, PLTD juga didesain untuk dapat memberikan RPM berdasarkan besarnya tegangan yang dibutuhkan dan dapat disetting sedemikian sesuai nilai yang diperlukan.

Jika generator sudah diparalel atau telah dihubungkan ke beban maka pada kondisi ini akan 
terjadi hubungan timbal balik yang saling mempengaruhi antara sistem tenaga listrik dan sistem mekanik. Pada setiap penambahan dan pengurangan beban akan berdampak terhadap RPM yang dihasilkan mesin. Pada setiap penambahan beban, maka fluks harus ditambah dengan memberikan arus magnet (Im) lebih besar, dan jika fluks semakin besar maka kuat medan (gaya magnet) juga akan lebih besar sehingga tegangan yang dihasilkan juga akan bertambah. Selain penambahan arus medan cara lain yang dapat kita lakukan untuk menghasilkan tegangan yang sesuai adalah dengan menambah gaya sentrifugal dan pada saat ini supply bahan bakar harus ditambah. Sehingga dapat disimpulkan bahwa penambahan beban sebanding dengan penambahan bahan bakar (Putaran) dan arus medan.

Untuk pengaturan supply bahan bakar, agar RPM tetap stabil dan tetap bersesuaian dengan keperluan tenaga listrik pada generator dilakukan oleh suatu alat yaitu Governor. Lebih dari fungsi ini governor juga dapat digambarkan sebagai alat komunikasi antara mesin diesel dengan energi listrik yang dihasilkan.

Governor adalah suatu alat kontrol yang bekerja secara elektromekanis, tetapi pada dasarnya untuk pengaturan supply bahan bakar kerja govenor adalah berdasarkan sistim mekanis yaitu dengan tuas-tuas penghubung dan roda-roda gigi yang dikopel satu sama lain. Inputnya diambil dari poros mesin dan output disambungkan ke handle bukaan valve bahan bakar.

Tipe governor yang sering digunakan di dunia industri adalah tipe UG40. governor UG40 ini mempunyai berat $45 \mathrm{Kg}$ tanpa peralatan bantu, kapasitas miyak 5,7 Liter (Oil Capacity) dan catu daya motor listriknya 240 Volt AC dengan arus 0,2 A dan faktor daya 0,85 .

Namun demikian dalam prakteknya Governor UG40 yang banyak dipakai pada pembangkit (PLTD) pada keluaran tahun 1980-an dan masih beroperasi sampai saat ini. Seperti di PT. Semen Padang masih terdapat kendala dalam setiap penarikan/pengurangan beban dalam jumlah besar (kira-kira lebih dari 50\% dari beban terpasang generator), yang menyebabkan pada kondisi ini kecepatan putaran mesin (RPM) akan berubah-ubah sehingga frekwensi dan tegangan juga akan berubah dalam rentang yang cukup besar.

Apabila terjadi perubahan frekuensi yang cukup besar baik itu penurunan ataupun kenaikan frekuensi maka akan dapat menyetop mesin listrik secara mendadak karena bekerjanya relay Over Speed atau relay Over Load.

Sebagai contoh pada PLTD di PTSP jika ada peralatan pabrik yang akan start $( \pm 2,5 \mathrm{MW})$ atau sebagian peralatan pabrik stop secara mendadak. Dalam beberapa kasus ada yang dapat menyetop mesin karena beban hilang dalam jumlah yang sangat besar seperti peralatan produksi pabrik stop secara mendadak sehingga frekwensi akan naik melebihi batas toleransi (diatas $54 \mathrm{~Hz}$ ) dan melewati batas waktu setting relay overspeed. Atau salah satu generator stop dengan mendadak akibat suatu gangguan sehingga frekwensi akan drop hingga $46 \mathrm{~Hz}$ atau lebih, dan jika melampaui batas waktu setting maka relay overload akan bekerja menyetop mesin.

Untuk membantu mengatasi kendala ini kerja governor dalam rangka mengatur supply bahan bakar dibantu secara manual dipanel listrik oleh operator. Yaitu dengan menghubungkan motor dua kumparan governor dengan switch dua posisi, yang selanjutnya motor berdasarkan respon yang diberikan oleh operator akan mengerjakan segmen-segmen mekanis governor sehingga respon governor juga akan lebih cepat. Selain untuk membantu bukaan bahan bakar dalam menormalkan RPM, switch ini juga berfungsi membantu mengatur supply bahan bakar untuk menaikkan putaran pada saat akan paralel dan menurunkan pada saat akan stop.

Untuk menghilangkan/mengurangi faktor dan peran operator dalam mekanisme penswitch-tan ini. Diharapkan agar Governor UG40 dapat bekerja lebih mendekati full otomatis dan untuk meminimalisir kemungkinan stopnya mesin maka penulis merancang suatu alat kendali yang diharapkan dapat bekerja sesuai yang dimaksudkan.

Dalam penelitian ini rancangan pengendali tersebut adalah berbasiskan mikrokontoller AT89S52. Dipilihnya AT89S52 sebagai kontrol didasarkan karena fleksibelitasnya yang tinggi. AT89S52 adalah IC keluaran ATMEL yang dibuat dalam bentuk mikrochip, dengan memori internal yang dapat diisi maupun dihapus berulang kali sehingga tidak perlu lagi menambah memori eksternal untuk menyimpan program yang akan kita gunakan untuk mengendalikan peralatan. Dengan konfigurasi demikian AT89S52 boleh dikatakan dapat menggantikan fungsi komputer dalam hal kontrol. Disamping itu output yang dihasilkan oleh AT89S52 dapat langsung digunakan sebagai pengontrolan dengan hanya menambahkan beberapa komponen saja, sehingga kita dapat membuat peralatan kontrol yang fleksibel, biaya rendah meskipun digunakan sebagai alat kontrol yang rumit sekalipun. Kelebihan mikrokontroller ini dibanding dengan rangkaian analog adalah dapat berkomunikasi dengan komputer dari serial port maupun port paralel. Sehingga dapat dikembangkan lebih jauh lagi.

Sebagai suatu kontrol peran governor sangat vital dalam setiap operasional pembangkit listrik karena governor inilah yang mengatur aktivitas pembangkit dengan product pembangkitan, dalam rangka supply bahan bakar. Oleh sebab itu lancar dan handalnya proses pembangkitan dan kwalitas tenaga listrik yang dihasilkan selain bergantung kepada kerja peralatan sistem mekanis dan generator serta komponennya juga sangat ditentukan oleh kwalitas dan kehandalan kerja Sistem Governor.

Prinsip dasar kerja governor adalah berdasarkan prinsip gaya sentrifugal, yang mana timbul karena adanya perputaran pada poros sehingga akan muncul 
suatu gaya gerak melingkar dengan suatu percepatan yang mengarah ke pusat/poros gerak melingkar tersebut, biasa disebut Gaya Sentrifugal/Sentripetal. Gaya ini akan timbul dan dipengaruhi oleh putaran mesin.

Atau secara ringkas teknis operasinya dapat dituliskan sebagai berikut :

Jika mesin sudah beroperasi maka putaran mesin akan memutar peralatan sistem sentrifugal governor melalui tuas penggerak utama ( Drive Shaft), dan putaran sistem ini akan mempengaruhi kerja batang penghubung governor ke pompa injeksi sehingga akan mengatur bukaan bahan bakar sesuai respon yang diberikan.

Untuk membantu kerja governor dalam rangka mengatur supply bahan bakar untuk penambahan dan pengurangan beban yang cukup besar dilakukan oleh sebuah motor listrik dua kumparan yang dioperasikan oleh operator dipanel. Yaitu menghubungkan motor tersebut dengan switch dua posisi, yang selanjutnya motor berdasarkan respon yang diberikan oleh operator akan mengerjakan segmen-segmen mekanis governor sehingga respon governor juga akan lebih cepat. Selain untuk membantu bukaan bahan bakar dalam menormalkan RPM, switch ini juga berfungsi membantu mengatur supply bahan bakar untuk menaikkan putaran pada saat akan paralel dan menurunkan pada saat akan stop.

Untuk menghilangkan/mengurangi faktor dan peran operator dalam hal penswitchan ini agar Governor UG40 PLTD II PTSP dapat bekerja lebih mendekati full otomatis, maka dirancang sistem kendali yang berbasiskan mikrokontoller AT89C51 untuk memfungsikan dan mengendalikan switch governor sehingga motor diharapkan dapat memenuhi tujuan yang dimaksudkan.

\section{METODE PERANCANGAN}

Perancangan ditujukan untuk mendapatkan hasil dari pembuatan alat yang baik sesuai yang diharapkan, dengan memperhatikan dan memilih penggunaan komponen yang sesuai dengan kebutuhan, serta mempertimbangkan aspek ekonomis, praktis, dan dinamis. Sehingga dengan perancangan dan perencanaan yang matang proses pembuatan secara bertahap dapat dilakukan dengan baik dan berkesinambungan. Dalam hal ini pemilihan metode dalam perancangan juga harus tepat agar benar-benar dapat membantu penyelesaian pembuatan alat ini.

\section{A. Perancangan}

Pada perancangan sistem kendali Governor UG40 dengan menggunakan mikrokontroller AT89S52 ini digunakan metode eksperimental. Dalam hal ini diartikan bahwa sasaran dari perancangan dan pembuatan sistem kendali ini dengan tujuan sebagaimana yang telah disebutkan benar-benar dapat dicapai. Karenanya pemilihan metode tersebut cukup tepat sebab rancangan sistem kendali ini juga atas dasar penelitian. Tahapan dan langkah-langkah yang telah disusun diharapkan dapat berjalan sesuai dengan item dan memenuhi target.

\section{B. Tahapan Perancangan}

Secara keseluruhan tahapan perancangan dapat dilihat seperti pada diagram alir berikut ini :

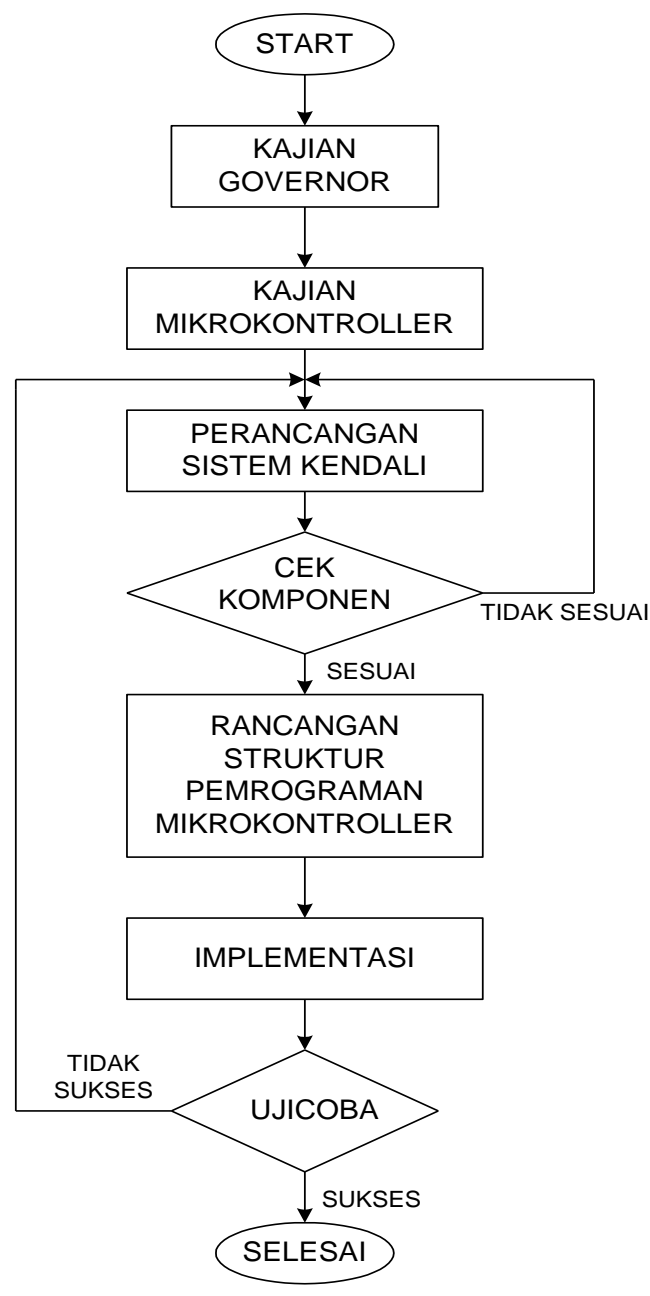

Gambar 1. Diagram Alir Perancangan

Tahap awal dari perancangan penelitian ini adalah kajian pustaka yang membahas teori-teori dasar tentang mesin arus bolak-balik, governor dan sistem kendali yang menggunakan mikrokontroller AT89S52. Kemudian melakukan perancangan sisten kendali mulai dari menggambar rangkaian, sampai pemasangan komponen-komponen. Tahap terakhir adalah pengujian dari alat. 


\section{Sistem Kerja PLTD dan Pengontrol}

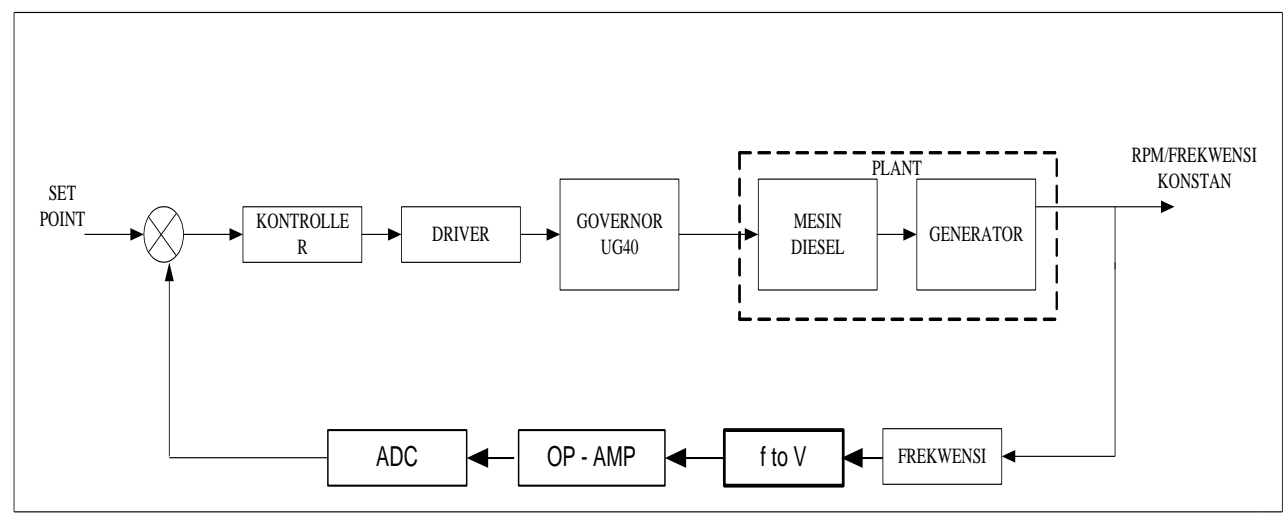

Gambar 2. Blok Diagram Sistem PLTD dan Pengontrol

Pada gambar diatas dapat dilihat sistem kendali dari PLTD.Mesin PLTD dikopel dengan generator.Untuk mengontrol mesin PLTD supaya mempunyai putaran yang sesuai dengan kebutuhan generator,dilakukan dengan cara mengendalikan governor. Sedangkan governor dikontrol oleh driver.
Driver yang digunakan adalah motor sinkron. Pada awalnya motor sinkron dikontrol oleh operator, tapi dengan pembuatan alat ini maka motor sinkron dapat dikontrol secara otomatis.

\section{Sistem Kerja Mikrokontroller AT89S52}

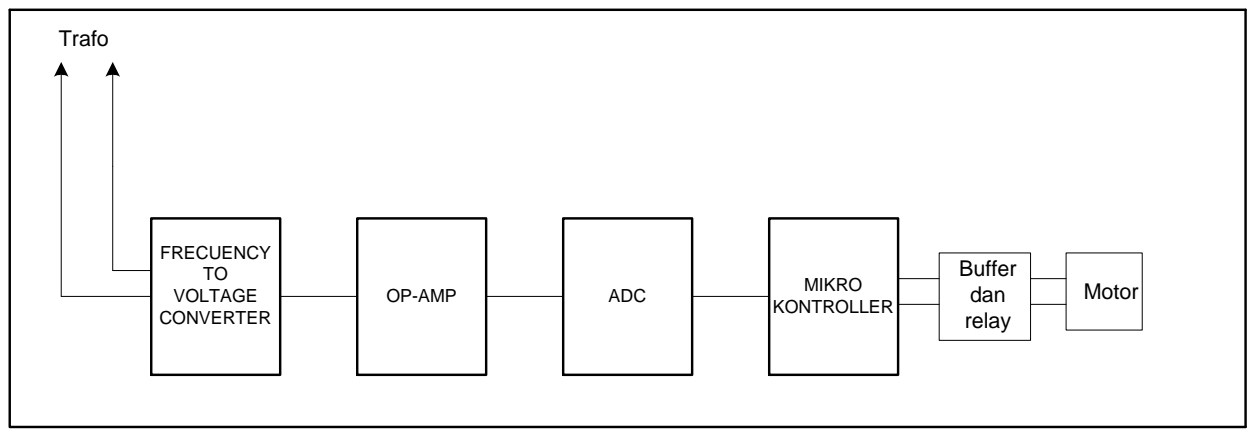

Gambar 3 : Blok Diagram Rangkaian Kontroller

\section{Keterangan :}

1. Op-Amp yang digunakan adalah tipe 324 .

2. Frequency to Voltage Converter adalah rangkaian elektronika dengan komponen utama IC LM 2917.

3. Analog to Digital Converter adalah rangkaian dengan komponen utama ADC nomor seri 0804.

4. Mikrokontroller AT89S52 keluaran ATMEL dengan 4 KB FLASH PEROM (Programable and Erasable Read Only Memory).

5. Buffer dan Relay, buffer yang digunakan adalah Transistor D400 NPN dan Transistor A733 PNP, Relay yang diguakan adalah Relay 6V DC.

Gambar di atas menerangkan sistem kerja dari alat yang akan dibuat.Frekwensi yang dihasilkan generator akan di inputkan pada $\mathrm{f}$ to v.f to $\mathrm{v}$ ini akan mengubah frekwensi yang dibaca dalam bentuk tegangan.Karena tegangan yang dihasilkan $\mathrm{f}$ to $\mathrm{v}$ relatif kecil maka diberi dulu penguatan melalui op-amp.Setelah dikuatkan melalui op-amp maka di inputkan pada
ADC yang akan mengubah tegangan analog menjadi tegangan digital (biner digit). Hasil dari perubahan ini akan di inputkan lagi pada mikrokontroller yang kemudian akan menggerakkan switch melalui triac.Sebelum data di inputkan pada mikrikontroller maka kita harus membuat perintah-perintah pada mikrokontroller yang sesuai dengan hasil penelitian sehingga pengontrolan yang dilakukan sesuai dengan apa yang diharapkan.

AT89C51 diproduksi dalam tiga bentuk IC yaitu PDIP (Plastic Dual Inline Package), PQFP/TQFP (Plastic Flat Package/Thun Plastic Gull Wing Quad Flat Package), dan PLCC (Plastic j-Leaded Chip Carrier). Namun yang dipakai dalam skripsi ini adalah IC dalam bentuk PDIP (Plastic Dual Inline Package) yang terdiri dari 40 pin. 


\section{HASIL DAN PEMBAHASAN}

Data penelitian diambil setelah perancangan dan perakitan alat selesai, Pengambilan data dimaksudkan untuk mencari data-data yang akan digunakan dalam membuat program. Pada pengambilan data, Peneliti harus men-set beberapa nilai komponen agar data yang didapat sesuai dengan yang diinginkan, Seperti nilai tahanan geser yang digunakan untuk mendapatkan tegangan referensi dari IC ADC (analog digital convert). Tegangan referensi dari IC ADC ini berfungsi untuk mendapatkan nilai set bilangan digital yang akan dicari, yaitunya setiap kenaikan tegangan 19,6 mV maka bilangan digital juga akan naik 1 bit. Disini peneliti mengambil perbandingan tegangan analog dengan tegangan digital 1:1. Hal ini dilakukan supaya lebih mudah dalam pengambilan data untuk membuat program dan mengacu kepada rumus tegangan digital,yaitu

$$
\frac{\text { tegangan.skala.penuh }}{2^{8}-1}=\frac{5 \cdot \text { volt }}{225}=19,6 \mathrm{mV} .
$$

Tegangan skala penuh disini adalah tegangan analog maksimal yang diterima oleh IC ADC dan 225 adalah besarnya tegangan digital yang dihasilkan oleh IC ADC delapan bit.

Tegangan yang keluar dari $\mathrm{F}$ to $\mathrm{V}$ masih sangat rendah sehingga bit yang dihasilkan oleh IC ADC tidak bisa dibedakan atau perbedaannya tidak terlihat jelas maka diberilah penguatan dengan menggunakan op-amp. Untuk memperoleh data yang jelas dalam pembuatan program dan mengetahui besarnya kenaikan tegangan digital maka penulis menggunakan lampu led sebagai indikator yang menandakan kenaikan tegangan digital sebesar satu bit setiap kenaikan 19,6 mV tegangan analog, Seperti yang dijelaskan diatas. Clock yang terdapat pada ADC berfungsi untuk menuliskan data yang dibaca oleh IC, Setiap kali terjadi perobahan data maka clock juga akan membaca data sesuai dengan perobahannya.

Dari tahapan pembuatan model sistem kendali yang telah dilakukan sampai memperoleh hasil yang diinginkan cukup banyak rintangan yang dihadapi terutama dalam hal mencari spesifikasi alat/bahan yang benar-benar sesuai. Pemilihan komponen pendukung dengan karakter dan nilai yang betul-betul memenuhi persyaratan juga kerap dibongkar pasang. Namun berkat perjuangan dan ketabahan akhirnya hasil yang dapat diangkat dan dipertanggungjawabkan sebagai sebuah tugas akhir.

Model yang dibuat tersebut diuji baik hardware maupun software. Tujuan pengujian ini untuk mengetahui sejauh mana keberhasilan alat yang dirancang serta membandingkan dengan spesifikasi yang diinginkan. Dari segi hardware dilakukan pengukuran tegangan pada masing-masing rangkaian serta kepekaan terhadap perubahan frekwensi dan tegangan, sedangkan untuk software masing-masing rangkaian dicek dengan membuat program pengetesan. Dimana program pengetesan tersebut disimpan dalam Flash PEROM mikrokontroller AT89S51

\section{A. Pengujian Dan Analisa}

Tahap ini adalah yang terakhir dari seluruh perencanaan dan pembuatan, dan diharapkan dapat menghasilkan sebuah sistem yang baik. Jika tidak memenuhi standar yang diinginkan maka proses kembali ke perancangan sistem kendali.

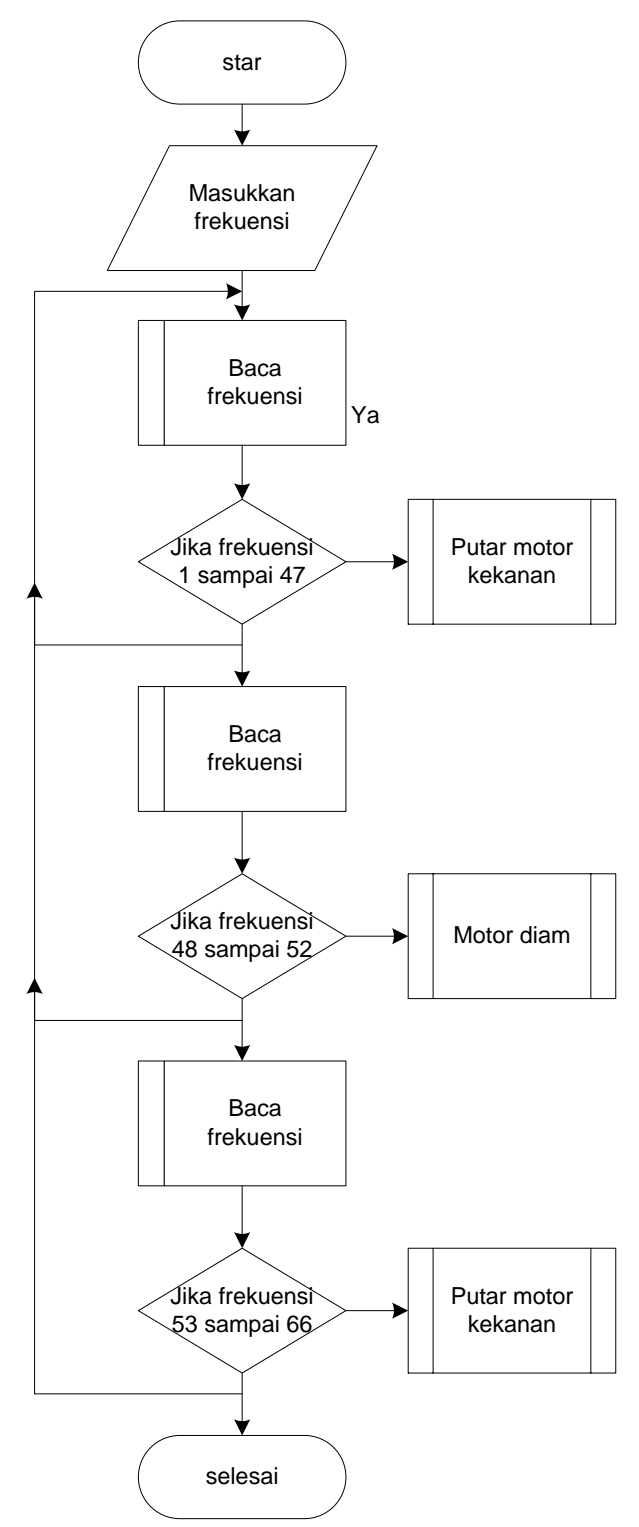

Gambar 4 : Gambar Flowchart Pengujian

Hasil analisa perhitungan ini telah diuji dengan pengetesan menggunakan rangkaian sebenarnya dan dengan simulasi Electronic Work Bench ( EWB ) dimana didapatkan hasil yang hampir sama dengan rumus tersebut. Hasil simulasi dengan EWB dapat digambarkan satu per satu sebagai berikut : 
1. Pada tegangan ( V2 ) 0.240 Volt $(F=48 \mathrm{~Hz})$

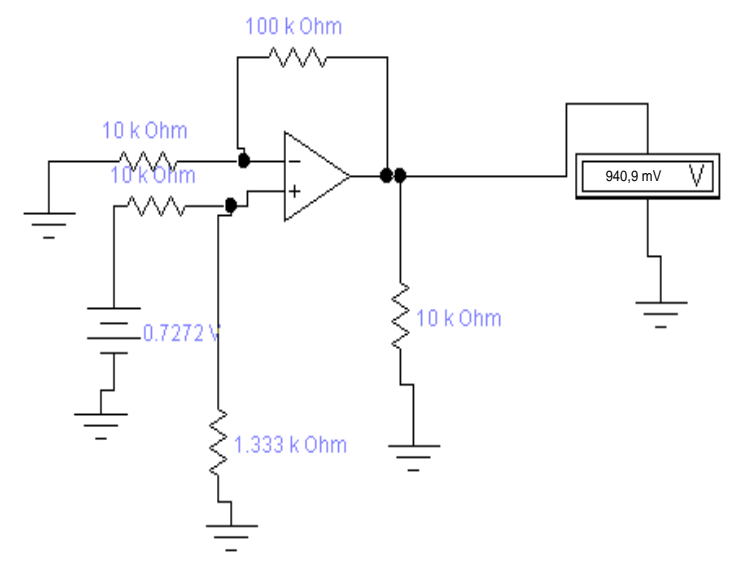

Gambar 5. Pengujian OP-amp dengan EWB

2. Pada tegangan ( V2 ) 0.245 Volt $(F=49 \mathrm{~Hz})$

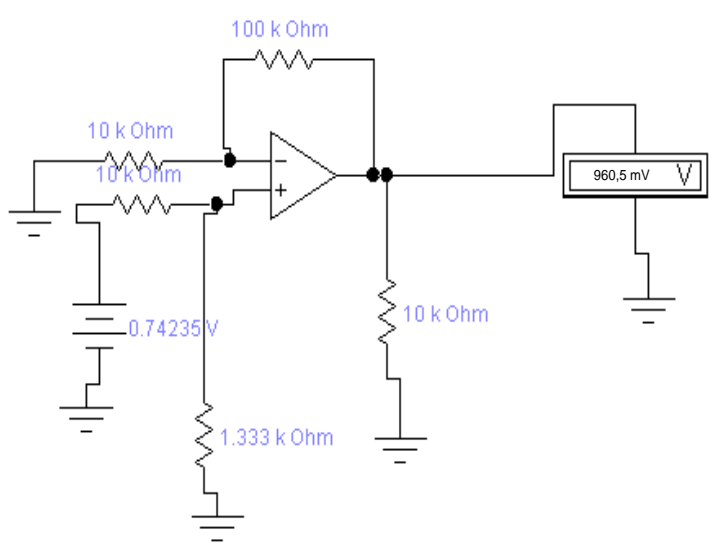

Gambar 6. Pengujian OP-amp dengan EWB

3. Pada tegangan ( V2 ) 0.250 Volt $(\mathrm{F}=50 \mathrm{~Hz})$

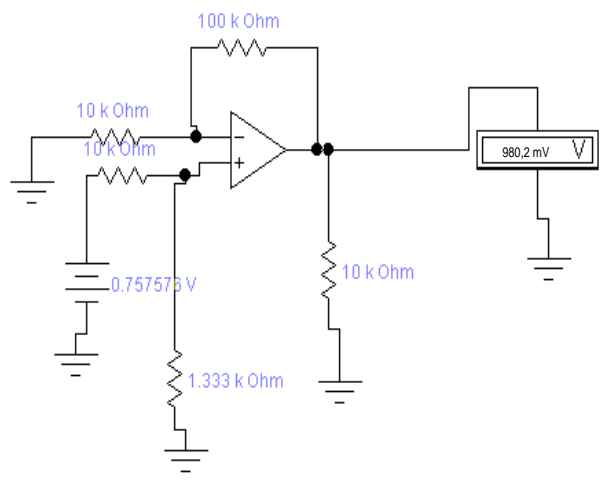

Gambar 7. Pengujian OP-amp dengan EWB
4. Pada tegangan ( V2 ) 0.255 Volt ( $\mathrm{F}=51 \mathrm{~Hz})$

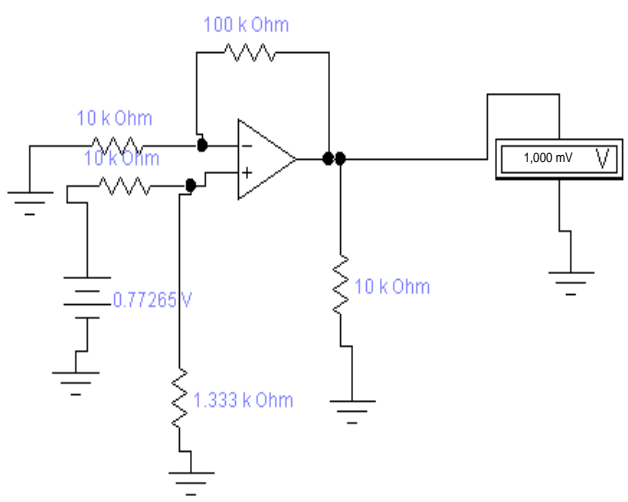

Gambar 8. Pengujian OP-amp dengan EWB

5. Pada tegangan ( V2 ) 0.260 Volt $(\mathrm{F}=52 \mathrm{~Hz})$

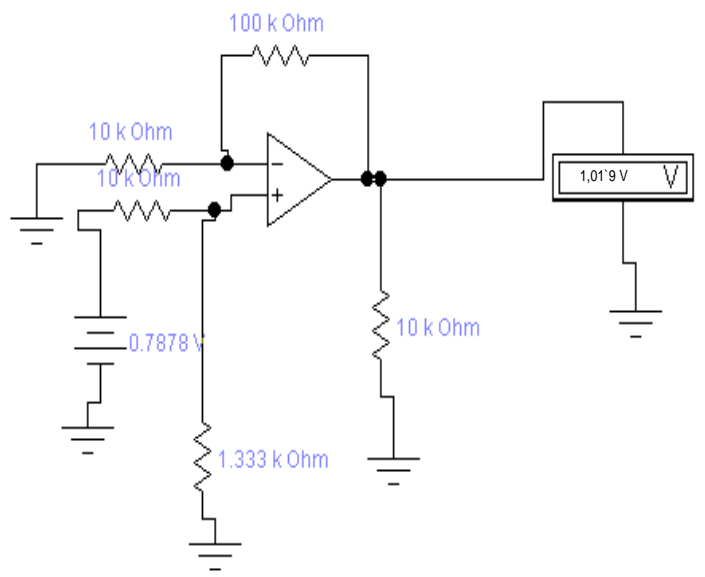

Gambar 9. Pengujian OP-amp dengan EWB

\section{B. Pengujian dan Data $A D C$}

Setelah dilakukan pemasangan ADC dan rangkaian Op-Amp sudah selesai diuji, maka rangkaian ADC juga akan dilakukan pengujian dengan merangkai seluruh item pengujian sebelumnya dan untuk memperoleh data atau gambaran hasil yang diinginkan pada output ADC dipasangkan LED-LED. 


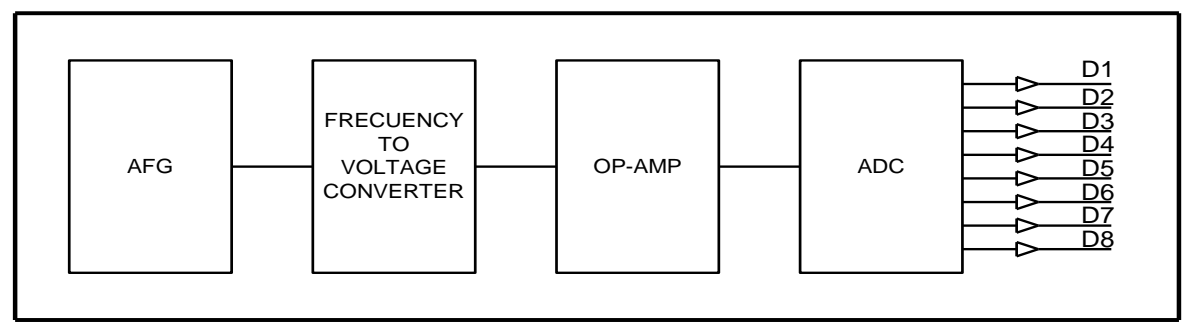

Gambar 10. Rangkaian Uji ADC

Data atau nilai-nilai yang diperoleh dari rangkaian uji ADC tersebut akan menyalakan LED-LED. Frekwensi yang dibangkitkan oleh AFG akan ditransfer oleh $\mathrm{F}$ to $\mathrm{V}$ menjadi tegangan, dan tegangan yang dihasilkan FTV diperkuat oleh Op-Amp seperti sudah dijelaskan sebelumnya. Tegangan yang berasal dari Op-Amp menjadi input bagi rangkaian ADC yang kemudian akan diinputkan ke mikrokontroller. Tabel berikut ini adalah data set-point tegangan analog yang di konversi kedalam bentuk tegangan digital

TABEL 1

DATA SET POINT NILAI DECIMAL TEGANGAN PENGUATAN

\begin{tabular}{|c|c|l|c|}
\hline No & $\begin{array}{c}\text { AFG } \\
\text { ( Hz })\end{array}$ & $\begin{array}{c}\text { V Op- } \\
\text { Amp } \\
\text { ( Volt })\end{array}$ & Decimal \\
\hline 1 & 48 & 0,9409 & 48 \\
2 & 49 & 0,9605 & 49 \\
3 & 50 & 0,9801 & 50 \\
4 & 51 & 1 & 51 \\
5 & 52 & 1,019 & 52 \\
\hline
\end{tabular}

Dengan pengujian menggunakan rangkaian seperti gambar 4.10 dan mengamati kedelapan buah LED ( 8 LED $=8$ bit ) yang hidup setiap perubahan input frekwensi dari AFG Jika diperhatikan hasil analisa dengan hasil pengujian rangkaian, didapatkan hasil yang hampir persis sama. Ini membuktikan bahwa rangkaian yang telah dibuat benar.

\section{PENUTUP}

\section{A. Kesimpulan}

Dari penelitian dan pengujian yang telah dilakukan dapat diambil beberapa kesimpulan antara lain :

1. Motor akan bekerja bila frekwensi yang dihasilkan diluar set point yang diberikan.

2. Jika frekwensi lebih dari $52 \mathrm{~Hz}$ maka model sistem kendali akan memberikan informasi berupa sinyal pada relay untuk melakukan penswitchan dan menyalurkan arus untuk memutar motor kearah kiri. Dan bila frekwensi kecil dari $48 \mathrm{~Hz}$ maka sistem akan memberikan sinyal ke relay untuk menswitch dan melewatkan arus guna memutar motor ke kanan untuk penambahan bahan bakar.
3. Alat ini tidak merespon besarnya tegangan input yang dimasukkan pada $\mathrm{F}$ to $\mathrm{V}$, tetapi alat ini akan merespon besarnya frekuensi yang di inputkan. Terbukti bahwa pada frekuensi yang sama dan tegangan yang berbeda, output dari $\mathrm{F}$ to $\mathrm{V}$ juga tidak berubah dan sebaliknya pada tegangan yang sama dan frekuensi yang berbeda, Maka output dari $\mathrm{F}$ to $\mathrm{V}$ juga akan berubah.

\section{B. Saran}

Dari pengalaman yang diperoleh selama melakukan penelitian dan pengujian model alat kendali ini ada beberapa saran yang ingin penulis kemukakan yaitu :

1. Untuk memperoleh hasil prototype yang lebih baik dengan tingkat kepekaan yang lebih tinggi dan ketelitian yang lebih akurat serta rentang set point yang makin dipersempit misal dari frekwensi 49 $\mathrm{Hz}$ sampai dengan $51 \mathrm{~Hz}$ disarankan untuk dapat melakukan penelitian lebih lanjut. Terutama bagi kawan-kawan yang berminat dan juga mempunyai kemampuan yang lebih baik.

2. Disarankan juga pada civitas elektro UNP terutama yang membuat tugas akhir menggunakan mikrokontroller sebaiknya menggunakan IC AT seri S, Karena IC seri ini downloadernya dapat kita buat sendiri dengan harga lebih ekonomis dan mudah dimengerti. Program kompilenya pun dapat berjalan secara otomatis.

\section{DAFTAR PUSTAKA}

[1] Agfianto Eko Putra, (2002). Belajar Mikrokontroller AT89C51/52/55 Teori dan Aplikasi. Yogyakarta : Gava Media.

[2] Anonim, (2006). Data Sheet, LM2917 Frequency to Voltage Converter.

[3] Anonim, (2006). Data Sheet, ADC0804.

[4] Djiteng Marsudi, (1990). Operasi Sistem Tenaga Listrik. Jakarta : Balai Penerbit dan Humas ISTN.

[5] Fredrick W. Hughes, (1994). Panduan Op-Amp. Jakarta : PT. Elex Media Komputindo.

[6] Margunadi, A.R. (1983). Pengantar Umum Elektroteknik. Jakarta : PT. Dian Rakyat.

[7] Woodward, (1984). UG40 Dial And Lever Governors : Woodward Governor Company. 
